\title{
Development of Visual Literacy Test Instrument on High School Physics Material
}

\author{
Erlita Agustina ${ }^{1, *}$ Supahar $^{1}$ \\ ${ }^{1}$ Physics Education, Graduate School, Universitas Negeri Yogyakarta, Sleman, Yogyakarta, Indonesia \\ "Corresponding author. Email: erlitaagustina23@gmail.com
}

\begin{abstract}
Developing test instruments that can be used to determine students' visual literacy skills on the subject of optics is the aim of this research. This research is a research development with the method of developing test instruments. The phases used in this study consisted of setting test objectives, determining competencies and the material being tested, compiling item distribution matrices, compiling test draft or blueprints, writing and assembling test items, compiling scoring rubrics, the validity of test items, revisions to improve items test, instrument assembly. The instrument used in this study was a questionnaire for the validation of the product being developed. The product developed was in the form of a test instrument to find out visual literacy skills with a multiple-choice format consisting of 5 items. The validation of the test instrument was carried out by 7 expert validators to assess the suitability of the questions on the test instrument with the available assessment indicators. The responses from the validators were analyzed using the Aiken $\mathrm{V}$ equation to determine the results of the content validity. The results of the content validity of the visual literacy skills test instrument on each item are $1 ; 0.93 ; 0.93 ; 1$; and 0.93 . These results provide the conclusion that the visual literacy skills test instrument is contentedly valid appropriate. This research has not been tested for reliability due to the constraints of the COVID-19 pandemic which has closed most schools and made it difficult to carry out reliability tests.
\end{abstract}

Keywords: Visual, Literacy, Instrument, Validity

\section{INTRODUCTION}

Physics is a branch of science. Physics learning directs students to be able to understand the concepts learned [1]. However, the abstract concept of physics makes students confused about learning it [2]. The difficulty in understanding abstract concepts from physics is one of the reasons students get low scores in physics. Research states that if abstract physics concepts are visualized well they can help to understand concepts [3]. Optics has become one of the materials contained in physics subjects. The results of the questionnaire given by Hermawan and Alifumi Arief [4] to students indicated that students still did not understand the optics material because there were students who were wrong in mentioning the various optical instruments and the law of reflection.

Optics material teaches about the parts of optical devices, formed shadow equations, the use of optical devices, and so forth. Optics material requires students to be able to observe parts and properties of images from optical instruments. The use of optical instruments itself is often encountered in everyday life [5]. Besides containing equations, optics also contains concepts that students must understand. The concepts in optics are often visualized such as parts of the eye, parts of microscopes, and other optical devices. The number of concepts visualized requires the ability of visual literacy to be able to understand it. Because many concepts can be visualized, the researcher focuses on visualizing the parts of the eye.

21 st-century education in Indonesia has 3 components as a reference for the quality of education. The 3 components include character, competence, and literacy [6]. The global world also makes literacy as a reference in the quality of education. Every country is competing to provide a good education for its citizens. The quality of education can be known after an assessment of the results of education in each country. 
The Organization for Economic Cooperation and Development (OECD) initiated an assessment program called the PISA (The Program for International Student Assessment). The results of the PISA assessment are expected to be a benchmark for the quality of education in Indonesia to form competent human resources to face the challenges of the 21 st century. Indonesia has been a PISA participant since 2000. The assessment conducted by PISA is carried out every 3 years with an assessment focus on basic literacy tests [7]. Visual literacy is a branch of literacy skills.

The ability to read, understand, evaluate, and create a visual object is a component of visual literacy skills. This description is supported by a statement the visual literacy is an individual's ability to do visual literacy in evaluating images. The part of the image that is evaluated can be the source of the image, the design of the image, the meaning of the media used, and the effectiveness of the existing image [8]. Other researchers suggest that visual literacy is the skill to create images and to extract meaning from visual objects [9]. The term visual literacy becomes a quality to be able to understand the meaning of visual objects, interpret, evaluate, and make images meaningful
[10]. The existence of visual literacy skills helps students to be able to describe an object [11]. Visual literacy can be used to support the ability to remember information and the ability of visual literacy is the same as the ability to think. A good visualization can enhance the ability of the knowledge possessed and can help when acquiring new knowledge that is still related. Making visual instructional can be used to develop visual literacy in teaching and learning activities. If the ability of visual literacy can be achieved, then students can follow the development of the era that is moved visually [12]. The level of visual literacy abilities possessed by students can be known by conducting tests using visual literacy instruments.

The test can measure something well if the instrument used has a good standard of testing. Some good test conditions are valid and reliable tests. The test must also be in accordance with the indicators of the variable to be achieved. Indicators of visual literacy can be seen in Table 1 and a draft of visual literacy test instruments in this study can be seen in Table 2 .

Table 1 Visual Literacy Indicator

\begin{tabular}{|l|l|l|}
\hline Aspect & Sub-aspect & Indicator \\
\hline \multirow{3}{*}{ Visual Literacy } & Reading visual object & Reading images or graphics \\
\cline { 2 - 3 } & Understanding the meaning of visual objects & $\begin{array}{l}\text { Explaining the meaning of images or } \\
\text { graphics }\end{array}$ \\
\cline { 2 - 3 } & Evaluating visual objects & Evaluating messages on visual objects \\
\cline { 2 - 3 } & Creating visual objects & Drawing messages into visual form \\
\hline
\end{tabular}

Table 2 Draft of Visual Literacy Test Instrument

\begin{tabular}{|l|l|l|l|l|l|}
\hline Aspect & Sub-aspect & $\begin{array}{l}\text { Visual Literacy } \\
\text { Indicator }\end{array}$ & Problem Indicator & $\begin{array}{l}\text { Cognitive } \\
\text { Level }\end{array}$ & Item Number \\
\hline Visual \\
Literacy & $\begin{array}{l}\text { Reading visual } \\
\text { object }\end{array}$ & $\begin{array}{l}\text { Reading } \\
\text { images or } \\
\text { graphics }\end{array}$ & $\begin{array}{l}\text { Presented a picture of the } \\
\text { eye part given letters and } \\
\text { a description of the } \\
\text { function of the eye part, } \\
\text { students mention the part } \\
\text { of the eye that matches } \\
\text { the description }\end{array}$ & C1 \\
\cline { 3 - 6 } & $\begin{array}{l}\text { Presented myopia eye } \\
\text { defects. Students are } \\
\text { asked to identify suitable } \\
\text { images }\end{array}$ & C1 & 1 \\
\hline
\end{tabular}




\begin{tabular}{|c|c|c|c|c|c|}
\hline Aspect & Sub-aspect & $\begin{array}{l}\text { Visual Literacy } \\
\text { Indicator }\end{array}$ & Problem Indicator & $\begin{array}{l}\text { Cognitive } \\
\text { Level }\end{array}$ & Item Number \\
\hline & $\begin{array}{l}\text { Understanding } \\
\text { the meaning of } \\
\text { visual objects }\end{array}$ & $\begin{array}{l}\text { Explaining the } \\
\text { meaning of } \\
\text { images or } \\
\text { graphics }\end{array}$ & $\begin{array}{l}\text { A picture of the eye defect } \\
\text { and a description of the } \\
\text { specific eye defect is } \\
\text { presented. The students } \\
\text { concluded their eye } \\
\text { defects }\end{array}$ & C4 & 2 \\
\hline & $\begin{array}{l}\text { Evaluating } \\
\text { visual objects }\end{array}$ & $\begin{array}{l}\text { Evaluating } \\
\text { messages on } \\
\text { visual objects }\end{array}$ & $\begin{array}{l}\text { An eye defect is given. } \\
\text { Students are asked to } \\
\text { recommend the } \\
\text { appropriate eyeglass } \\
\text { power/strength }\end{array}$ & $\mathrm{C} 4$ & 3 \\
\hline & $\begin{array}{l}\text { Creating visual } \\
\text { objects }\end{array}$ & $\begin{array}{l}\text { Drawing } \\
\text { messages into } \\
\text { visual form }\end{array}$ & $\begin{array}{l}\text { Was given a description } \\
\text { of a person's eye defects. } \\
\text { Students draw } \\
\text { illustrations in accordance } \\
\text { with the eye defects they } \\
\text { have suffered }\end{array}$ & C4 & 4 \\
\hline
\end{tabular}

\section{RESEARCH METHOD}

The method used in this research is the method of developing a test instrument developed by Edy Istiyono [13].

\subsection{Type of Research}

This research is research development. The product was developed in the form of a visual literacy test instrument with a multiple-choice format. This test instrument is used to measure the visual literacy skills of high school students on the subject of optics. Products are developed according to the procedure of developing test instruments. The stages of the instrument development procedure consist of 11 stages, namely the determination of test objectives, determination of competencies and the material being tested, a compilation of the item distribution matrix, preparation of the test draft or blueprint, writing and assembling test items, a compilation of the scoring rubric, the validity of the test items, revisions to improve test items, instrument assembly, test trials, and main test tests [13]. However, the procedure of this research is limited to nine stages of assembling the test instrument and has not yet reached the stage of trial testing and primary test. So, the development procedures used in this research consisted of determination of test objectives, determining competencies and the material being tested, compiling item distribution matrices, compiling test draft or blueprints, writing and assembling test items, a compilation of scoring rubrics, test item validity, revisions to improve test items, and instrument assembly.

\subsection{Data Collection Techniques}

Data collection was done by using a non-test technique using a validated questionnaire. Validation was carried out by 7 expert validators. The validation questionnaire has 3 aspects including material aspects, construction aspects, and language aspects where each aspect consists of 3 indicators that are assessed.

\subsection{Data Analysis Techniques}

Data from the results of the questionnaire judgment of the visual literacy test instrument from 7 expert validators were analyzed using the Aiken $\mathrm{V}$ equation in Equation (1) to reveal the validity of each item on the visual literacy test instrument. The Aiken Equation V used is:

$V=\frac{\Sigma s}{n(c-1)}$

The description of the above equation $V$ is the Aiken validity index, $s$ is the difference between the value given by the validator and the lowest validity evaluator, $n$ is the number of validators, and $c$ is the highest validity estimator.

After obtaining quantitative data from expert scores and data analysis then the data is converted into qualitative data to describe the quality of the content validity of the test instruments.

\section{RESULT AND DISCUSSION}

The results of problem identification become the basis of the development of this visual literacy test 
instrument. The development of this test goes through several stages of test development. The first stage is to determine the test objectives. The purpose of this test itself is to determine the level of visual literacy skills students have.

The second stage is to determine the competence and material to be tested. Competence needed to be able to achieve visual literacy skills can be seen in Table 1. The optical instrument material taught in class XI SMA has a concept that is often visualized so the material is suitable for use in this developed test.

The third stage of developing a test is creating a matrix. Distribution matrices are made based on indicators of visual literacy and the material selected for

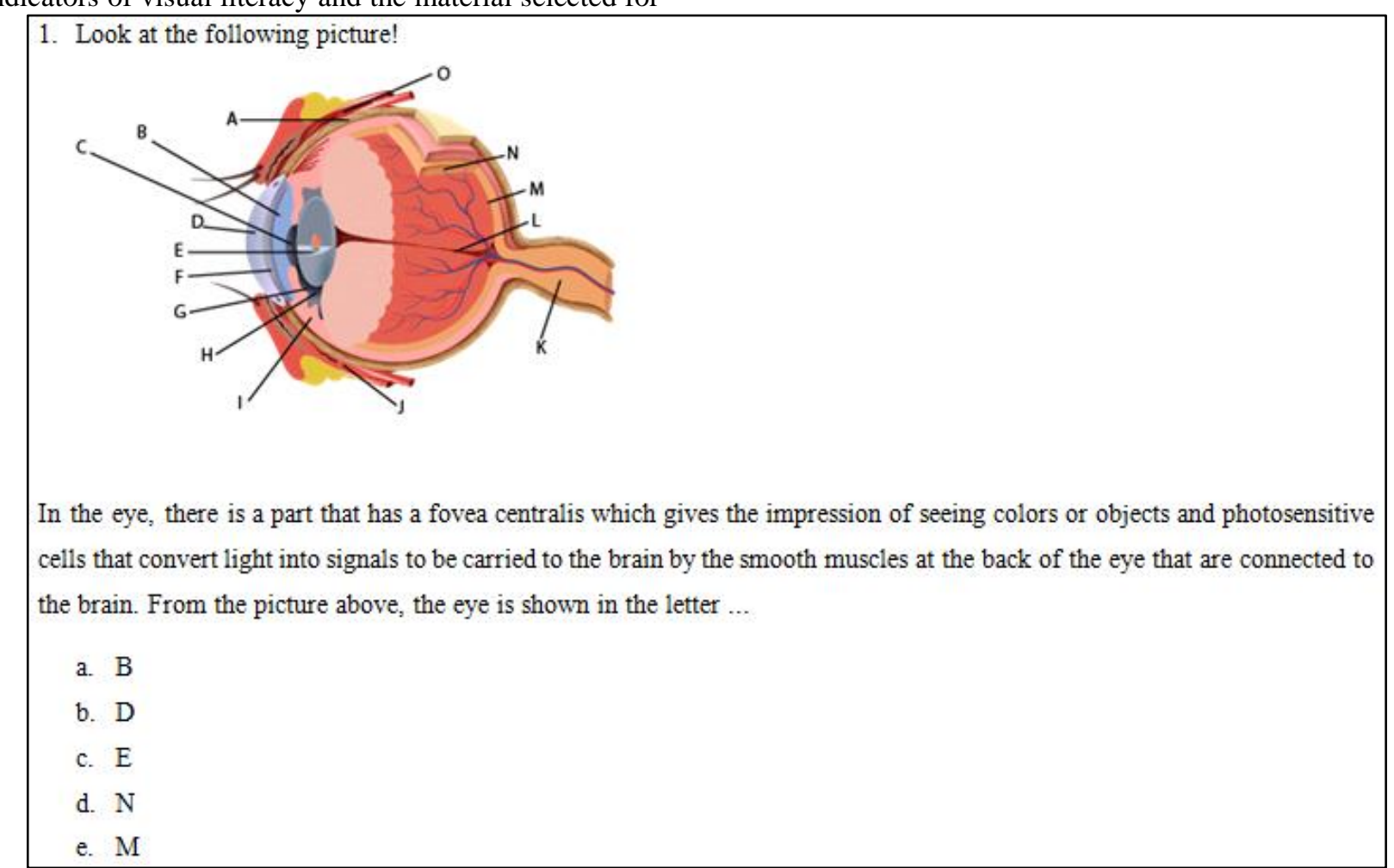

Figure 1 Visual literacy problems for optical materials

The next stage is to compile a scoring rubric. The scoring rubric is made to provide a score for each question if it is answered correctly or if it is answered incorrectly by students. If the student answers one question correctly, the student gets a score of 1 . If the student answers one question with the wrong answer then the student gets a score of 0 .

The validation stage of the visual literacy test instrument was carried out by 7 experts to determine whether the instrument developed was suitable for use and could measure visual literacy skills. The validator assesses the appropriateness of the visual literacy test instrument based on 3 aspects, namely material aspects, construction aspects, and language aspects question numbers. The visual literacy test on optics material contains 5 questions.

The stage of making a blueprint for each question number makes a description that draws the question that is made. The blueprint of the visual literacy test is shown in table 2.

The next stage is to write and assemble the test. Visual literacy tests are made in the form of a simple multiple choice. An example of one of the numbers of visual literacy tests that have been developed can be seen in Figure 1.
The validation process is carried out in detail on each item so that the test instrument is truly feasible and can be used to measure what will be measured. The results of the analysis are said to be valid if they meet the Aiken V limit requirements [14]. The Aiken $\mathrm{V}$ index limit requirement with 3 rating scales and 7 raters is 0.86 [15]. Each item on the visual literacy test instrument has an Aiken $\mathrm{V}$ index of more than 0.86 so from these results, it can be concluded that the test instrument is fit to enter the testing phase. The results of validation by experts on each item can be seen in Table 3 . 
Table 3 Validation Results

\begin{tabular}{|c|c|c|}
\hline $\begin{array}{r}\text { Item } \\
\text { Number }\end{array}$ & Number of Aiken & Result \\
\hline 1 & 1 & Valid \\
\hline 2 & 0.93 & Valid \\
\hline 3 & 0.93 & Valid \\
\hline 4 & 1 & Valid \\
\hline 5 & 0.93 & Valid \\
\hline
\end{tabular}

After going through the content validation stage, the questions were revised according to the suggestions given by the validator so that the instrument was suitable for use in the trial phase. The trial phase was carried out to determine the reliability and construct validity of the visual literacy test instrument. Unfortunately, this research did not reach the trial stage because the COVID19 pandemic caused school closures and it was difficult to carry out trials.

\section{CONCLUSION}

The conclusion obtained from the results of this research is that the visual literacy skills test instrument on the subject of the developed optical instrument is declared contentedly valid and suitable for use at the trial stage. However, the instrument in this research has not yet reached the trial stage so for further research it is recommended to be able to carry out the trial phase in schools.

\section{AUTHORS' CONTRIBUTIONS}

All authors contributed to making the script, starting from ideas, data analysis, and scriptwriting. All authors have checked the contents of the manuscript carefully and have agreed to the publication of the manuscript results of this research.

\section{ACKNOWLEDGMENTS}

Author would like to thank, for State High School 9 Pandeglang, State High School 1 Banjarharjo, and Integrated Islamic Senior High School Abu Bakar Boarding School

\section{REFERENCES}

[1] N. Eliana, T. Prihandono, S. Wahyuni. Pengembangan Modul Alat-Alat Optik berbasis Pictorial Riddle pada Mata Pelajaran Fisika di Madrasah Aliyah, in: Seminar Nasional Pendidikan Fisika 2017, 2, Universitas Negeri Jember, Jember, 2017, pp 1-7
[2] A. Furoidah, Indrawati, R. Wahyu. Identifikasi Miskonsepsi Konsep Dinamika Rotasi dengan Metode Four Tier pada Siswa KElas XI SMA Negeri 3 Jember, in: Seminar Nasional Pendidikan Fisika 2017, 2, Universitas Negeri Jember, Jember, 2017, pp 1-7

[3] Gunawan, A. Harjono, H. Sahidu, Sutrio. Penggunaan Multimedia Interaktif dalam Pembelajaran Fisika dan Implikasinya pada Penguasaan Konsep Mahasiswa, J. Pijar MIPA. 9 (2014), pp. 15-19. DOI: 10.29303/jpm.v9i1.38

[4] Hermawan, A. Arief. Pengembangan Perangkat Kurikulum 2013 melalui Pendekatan Scientific pada Materi Alat Optik untuk Melatihkan Sikap Ilmiah Siswa Kelas X SMAN 3 Surabaya, J. Inov. Pendidik. Fis. 3 (2014), pp. 96-102

[5] D. E. Wahyuni, A. Arief. Implementasi Pembelajaran Scientific Approach dengan Soal Higher Order Thinking Skill pada Materi Alat-Alat Optik Kelas X di SMA Nahdlatul Ulama' 1 Gresik, J. Inov. Pendidik. Fis. 4 (2015), pp. 32-37

[6] A. Widodo, D. Indraswati, M. Sobri. Analisis NilaiNilai Kecakapan Abad 21 dalam Buku Siswa SD/MI Kelas V Sub Tema 1 Manusia dan Lingkungan, Tarb. J. Ilm. Kependidikan. 8 (2019), pp. 125-133. DOI: 10.18592/tarbiyah.v8i2.3231

[7] I. Pratiwi. Efek Program PISA terhadap Kurikulum di Indonesia, J. Pendidik. dan Kebud. 4 (2019), pp. 51-71. DOI: 10.24832/jpnk.v4i1.1157

[8] D. M. Baylen, A. D'Alba. 2015 Essentials of Teaching and Integrating Visual and Media Literacy Visualizing Learning, Springer International Publishing, Switzerland, 2015, p. xiv. DOI: 10.1007/978-3-319-05837-5

[9] G. Benoît. The 'Beautiful' in Information: Thoughts about Visual Literacy adn Aesthetics, J. Vis. Lit. 35 (2016), pp. 60-78. DOI: 10.1080/1051144X.2016.1205831

[10] J. Sibanda, L. Sibanda. Visual Literacy Development through the Mediation of Grade 4 English Textbooks, J. Vis. Lit. 32 (2013), pp. 3966. DOI: $10.1080 / 23796529.2013 .11674709$

[11] S. Sidhartani. Literasi Visual sebagai Dasar Pemaknaan dalam Apresiasi dan Proses Kreasi Visual, J. Desain. 03 (2016), pp. 155-63. DOI: 10.30998/jurnaldesain.v3i03.709

[12] S. Nurannisaa P.B. Menghadapi Generasi Visual; Literasi Visual untuk Menstimulasi Kemampuan Berpikir dalam Proses Pembelajaran, ELSE (Elementary Sch. Educ. Journal) J. Pendidik. dan 
Pembelajaran Sekol. Dasar. 1 (2017), pp. 48-59. DOI: 10.30651/else.v1i2a.1043

[13] E. Istiyono. Pengembangan Instrumen Penilaian dan Analisis Hasil Belajar Fisika dengan Teori Tes Klasik dan Modern, UNY Press, Yogyakarta, 2018, pp. 380-393

[14] K. Bashooir, Supahar. Validitas dan Reliabilitas Instrumen Asesmen Kinerja Literasi Sains Pelajaran Fisika berbasis STEM, J. Penelit. dan Eval. Pendidik. 22 (2018), pp. 219-230. DOI: 10.21831/pep.v22i2.19590

[15] L. R. Aiken. Three Coefficients for Analysing Reliability and Validity of Ratings, Educ. Psychol. Meas. 45 (1985), pp. 131-142. DOI: $10.1177 / 0013164485451012$ 